\title{
Vasoactive Intestinal Peptide Is Critical for Circadian Regulation of Glucocorticoids
}

\author{
Dawn H. Loh Catalina Abad Christopher S. Colwell James A. Waschek \\ Semel Institute for Neuroscience, Mental Retardation Research Center, Department of Psychiatry and \\ Biobehavioral Sciences, University of California, Los Angeles, Calif., USA
}

\section{Key Words}

Vasoactive intestinal peptide $\cdot$ Circadian rhythms •

Glucocorticoids $\cdot$ Hypothalamic-pituitary-adrenal axis •

Stress $\cdot$ Photic induction ly unaltered by the loss of VIP. Conclusion: Thus, our data demonstrate that VIP is essential for the circadian regulation of an otherwise intact hypothalamic-pituitary-adrenal axis.

Copyright $\odot 2008$ S. Karger AG, Basel

\section{Introduction}

In mammals, the timing and occurrence of many physiological processes critically depends on the proper functioning of the suprachiasmatic nucleus (SCN). Current thinking places the $\mathrm{SCN}$ at the head of a hierarchy of oscillators distributed throughout a mammalian body [1, 2]. The SCN plays interwoven dual roles, taking in light information from the environment to organize peripheral oscillators, as well as synchronising these oscillators even in the absence of external cues. Output signals from the SCN include neuronal signals and secreted factors that govern downstream rhythms in behavior and endocrinology.

One of the downstream rhythmic signals is the daily rise in circulating corticosterone that occurs just prior to waking in mammalian species. It is postulated that this rise prepares an animal for the various stressors that are associated with activity onset, acting as a global signal for various processes like metabolism and the immune

\section{KARGER}

Fax +4161306 1234

E-Mail karger@karger.ch

www.karger.com
(C) 2008 S. Karger AG, Basel

Accessible online at: www.karger.com/nen
C.S. Colwell

University of California - Los Angeles

760 Westwood Plaza

Los Angeles, CA 90024-1759 (USA)

Tel. +1 310206 3973, Fax +1 310206 5060, E-Mail ccolwell@mednet.ucla.edu 
system. Glucocorticoid and mineralocorticoid receptors have a widespread distribution in the peripheral organs as well as throughout the central nervous system but are not found in the SCN [3], suggesting that the daily increase in corticosterone concentration could act as a unidirectional output signal from the SCN.

The circuitry by which the SCN regulates the hypothalamic-pituitary-adrenal (HPA) axis has been previously studied. Anatomical studies have provided evidence that the paraventricular nucleus (PVN) receives innervations from the SCN. Release of corticotropin-releasing factor (CRF) by neurons within the PVN is the critical step in stimulating ACTH release from the pituitary and thus the activation of the HPA axis [4]. In this manner, the SCN could provide circadian information to the HPA axis by direct innervation. Furthermore, SCNlesioned rats show a loss of daily rhythm in ACTH and corticosterone [5-7]. Transplantation of fetal SCN tissue into SCN-lesioned hamsters does not restore the loss of glucocorticoid rhythmicity even though rhythms in voluntary wheel-running behavior are restored [8]. These lines of evidence point towards the necessity of synaptic connections between the SCN and the PVN for circadian regulation of at least some endocrine rhythms. Of the SCN neurons that project to the PVN, a large number use the neuropeptide vasoactive intestinal peptide (VIP) as a signaling molecule $[9,10]$. Application of VIP into the hypothalamus, close to the PVN increases circulating ACTH and corticosterone concentration [11]. It is thus a potential regulator of the circadian drive of the HPA axis.

We have previously shown that mice lacking VIP have deficiencies in circadian behavior, including poor locomotor rhythmicity under conditions of constant darkness and inappropriate responses to phase-shifting light pulses [12]. The receptor for VIP in the SCN is the VPAC 2 receptor, mutants of which also have pronounced circadian defects $[13,14]$. Additionally, the SCN of VIP-deficient and $\mathrm{VPAC}_{2} \mathrm{R}$ mutant mice have fewer intrinsically rhythmic cells, and those that remain rhythmic show a lack of synchrony of electrical firing with each other $[15$, 16]. This suggests the underlying cause of the circadian deficiencies to be within the SCN, due to both loss of intrinsic rhythmicity within each SCN neuron as well as defects in coupling of rhythms between SCN neurons. It also makes VIP-deficient mice a useful model in which to study the effects of an arrhythmic SCN on neuroendocrine output. Previous lesion studies have demonstrated the need for an intact SCN for neuroendocrine rhythms. However, electrolytic or physical cutting in the hypothal- amus might damage connections with neighboring nuclei. In the case of VIP-deficient mice, the SCN are still anatomically intact, albeit without the developmental and functional expression of VIP. We can thus determine the necessity of SCN rhythmicity on the circadian responses in the periphery. To this end, we designed our study to test the hypothesis that VIP plays a critical role in conveying time of day information within the HPA axis.

\section{Materials and Methods}

\section{Experimental Animals}

Our studies to measure diurnal and circadian circulating glucocorticoid concentrations and the effect of adrenalectomy on glucocorticoid concentrations utilized adult male offspring of F1 $\mathrm{C} 57 \mathrm{BL} / 6 \mathrm{~J} \times 129 / \mathrm{Sv}$ mice lacking the gene encoding for VIP and PHI: $V_{i p^{-1-}}$. Wild-type controls from the same litter were analyzed when available, but controls from other age-matched litters were used when necessary. Response to acute stress and light treatment was measured in male $\mathrm{Vip}^{-1-}$ mice on a C57BL/6J background (backcrossed for 12 generations) with age-matched controls from inbred C57BL/6J lines. In all studies, the recommendations for animal use and welfare, as dictated by the UCLA Division of Laboratory Animals and the guidelines from the National Institutes of Health, were followed.

\section{Behavioral Analysis}

Male mice of at least 10 weeks of age were housed individually and their wheel-running activity was recorded as revolutions per 3-min interval. The running wheels and data acquisition system were obtained from Mini Mitter Co. (Bend, Oreg., USA). The mice were exposed to a 12:12 light-dark cycle (LD) for 2-3 weeks (light intensity $36 \mu \mathrm{W} / \mathrm{cm}^{2}$, approx. $120 \mathrm{~lx}$ ). The mice were then placed into constant darkness (DD) to assess their free-running activity pattern. Circadian time (CT) was determined by activity records with activity onset denoted as CT12. Sample collections and treatments in DD were typically performed after 2-4 days in constant darkness. In the dark portion of LD conditions, as well as under DD conditions, handling of mice was carried out with the aid of an infrared viewer (FJW Industries, Ohio, USA).

\section{Adrenalectomy}

Bilateral adrenalectomies were performed through dorsal incisions under anesthesia by ketamine/xylazine. Sham operations were performed in a similar fashion with the exception that the adrenal glands were left intact. Following surgery, adrenalectomized (ADX) mice received a $0.9 \% \mathrm{NaCl}$ solution to drink. Blood was collected by terminal cardiac puncture under isoflurane anesthesia in late day (ZT10) 3 weeks after adrenalectomy.

\section{Induction of Stress in Mice}

Acute stress was applied in early night at Zeitgeber time (ZT) $15,3 \mathrm{~h}$ after lights-off, in the form of an underfoot stimulus (0.5 $\mathrm{mA}$, footshock) as previously described [17]. Following the footshock, mice were returned to their home cages and anesthetized 
with isoflurane $20 \mathrm{~min}$ after initial introduction to the stress protocol. Trunk blood was collected after decapitation for glucocorticoid assays. In a separate experiment to determine induction of gene expression in the adrenal glands, following footshock, mice were returned to their home cages and anesthetized with isoflurane $60 \mathrm{~min}$ after initiation of the stress protocol. Adrenal glands were dissected following decapitation and immediately homogenized in Trizol.

\section{Acute Light Treatment}

A submaximal (15 $\mu \mathrm{W} / \mathrm{cm}^{2}$, approx. $\left.50 \mathrm{~lx}\right)$ light treatment was applied in early night (ZT16) for $30 \mathrm{~min}$, after which the mice were returned to dark conditions for an additional $30 \mathrm{~min}$. Trunk blood was sampled after anesthesia with isoflurane. The same light treatment was applied to free-running mice in early night (CT16) in a separate experiment to determine induction of gene expression in the adrenal glands. $60 \mathrm{~min}$ after the initiation of the light treatment, mice were anesthetized, decapitated and the adrenal glands dissected and homogenized in Trizol.

\section{Glucocorticoid Assays}

To obtain serum, blood samples were allowed to clot at room temperature for $30 \mathrm{~min}$ prior to centrifugation at $1,000 \mathrm{~g}$. The supernatant was stored at $-20^{\circ} \mathrm{C}$ until assayed. Serum ACTH concentration was determined using a commercially available competitive enzyme immunoassay (ACTH 1-39 EIA, Peninsula Laboratories, Calif., USA). The intra-assay coefficient of variation $(\mathrm{CV})$ was $<5 \%$, the inter-assay CV was $<14 \%$ and the sensitivity was $0.04-0.06 \mathrm{ng} / \mathrm{ml}$. Serum samples were typically diluted between 2 - and 10 -fold prior to assay. Serum corticosterone concentration for the round-the-clock and adrenalectomy experiments were measured by competitive enzyme immunoassay (R\&D Systems, Minn., USA). Intra-assay precision was $<8.4 \%$, inter-assay $\mathrm{CV}$ was $<13.1 \%$ and sensitivity was $27 \mathrm{pg} / \mathrm{ml}$. Samples were typically diluted between 8 - and 150 -fold prior to assay. Due to discontinuation of the R\&D corticosterone EIA kit, serum corticosterone concentration for the acute stress and light treatment experiments was measured using a different competitive enzyme immunoassay (Correlate-EIA Corticosterone kit, Assay Designs, Mich., USA). The intra-assay CV was $<8 \%$, the inter-assay $\mathrm{CV}$ was $<13.1 \%$ and the sensitivity was $27 \mathrm{pg} / \mathrm{ml}$. Serum samples were diluted 100 -fold prior to assay.

\section{Quantitative Real-Time PCR}

RNA was extracted from adrenal glands using the Trizol (Invitrogen) procedure and treated with DNase (Turbo DNA-free, Ambion) for $30 \mathrm{~min}$ to remove possible DNA contaminants. cDNA was obtained by reverse-transcription of $1 \mu \mathrm{g}$ total RNA (High Capacity cDNA Reverse Transcription Kit, Applied Biosystems) and no-RT controls were run routinely. Primers for Per1 and Hprt were designed using Oligo6 (Molecular Biology Insights) and Mfold [18] programs to cross intron-exon boundaries and hence further prevent contaminants in the subsequent RTPCR. Oligonucleotide primer sequences used were Perl-sense: $5^{\prime}$ TCC TCC TCC TAC ACT GCC TCT- ${ }^{\prime}$ and Perl-antisense: $5^{\prime}$ TTG CTG ACG ACG GAT CTT T-3'; and Hprt-sense: 5'-TGG TGA AAA GGA CCT CTC GAA-3' and Hprt-anti-sense: $5^{\prime}$-TCA AGG GCA TAT CCA ACA ACA-3'. PCR products from each primer pair were cloned and sequenced to confirm specificity as well as run on an agarose gel to ensure no primer dimers were formed. Quantitative PCR using SyBr Green (SYBR Green PCR Master Mix, Applied Biosystems) was performed using the equivalent of $50 \mathrm{ng}$ of starting total RNA (1:20 of the initial cDNA reaction from $1 \mu \mathrm{g}$ of total RNA) in a $25-\mu$ l reaction comprising of the $2 \times$ SYBR Green reaction mix and $1.2 \mu \mathrm{M}$ each of the forward and reverse primers. The efficiency of each primer pair was confirmed prior to experimental use by serial dilutions of a cDNA sample, and by plotting $C t$ (cycle number at which threshold within the linear range was reached) values against $\log _{\text {(total RNA). Melting }}$ curves were determined at the end of each reaction to check product specificity. The relative levels of Perl transcripts were determined using the $2^{-\Delta \Delta \mathrm{Ct}}$ method, using Hprt as the normalizing reference gene.

\section{Statistical Measurements}

Between-group differences were generally determined by $t$ tests or Mann-Whitney rank sum tests when appropriate. Values were considered significantly different if $\mathrm{p}<0.05$. All tests were performed using GraphPad Prism or SigmaStat. In the text, values are shown as mean \pm SEM.

\section{Results}

\section{Deficits in Diurnal Rhythms of Glucocorticoids in}

$\mathrm{Vip}^{-/}$Mice

We first determined concentration of corticosterone in serum across a 24-hour period in normal lighting conditions of 12:12 h LD (fig. 1a). Blood was sampled from wild-type (WT) and Vip ${ }^{-1-}$ (VIP KO) mice every $3 \mathrm{~h}$ $( \pm 1 \mathrm{~h}$ to accommodate multiple sampling), starting at $2 \mathrm{~h}$ after lights-on (ZT2). We next determined circulating corticosterone concentration for both WT and VIP KO mice every $4 \mathrm{~h}$ in DD at CT points determined by locomotor activity (fig. 1b). As CT is calculated based on voluntary wheel running activity and VIP $\mathrm{KO}$ mice have varied locomotor activity patterns [12], only behaviorally rhythmic mice were used. We found that WT mice exhibit a strong rhythm in circulating corticosterone in both LD and DD ( $p<0.001$ and $p<0.05$ by ANOVA), with a daily rise in either late day or late subjective day, respectively. In contrast, VIP KO mice did not exhibit a daily rhythm under either condition.

Further characterization of the effect of loss of VIP on endocrine function was carried out by determining concentration of circulating ACTH over the course of a 24hour day in LD (fig. 2a). Serum ACTH was measured for WT and VIP KO mice in the same manner as for corticosterone. The serum concentration of ACTH in DD was also measured (fig. 2b). We found that WT mice display a clear rhythm in ACTH under LD as well as DD ( $\mathrm{p}<$ 0.01). VIP KO mice, on the other hand, do not have rhythmic ACTH concentration. In addition, basal concentra- 


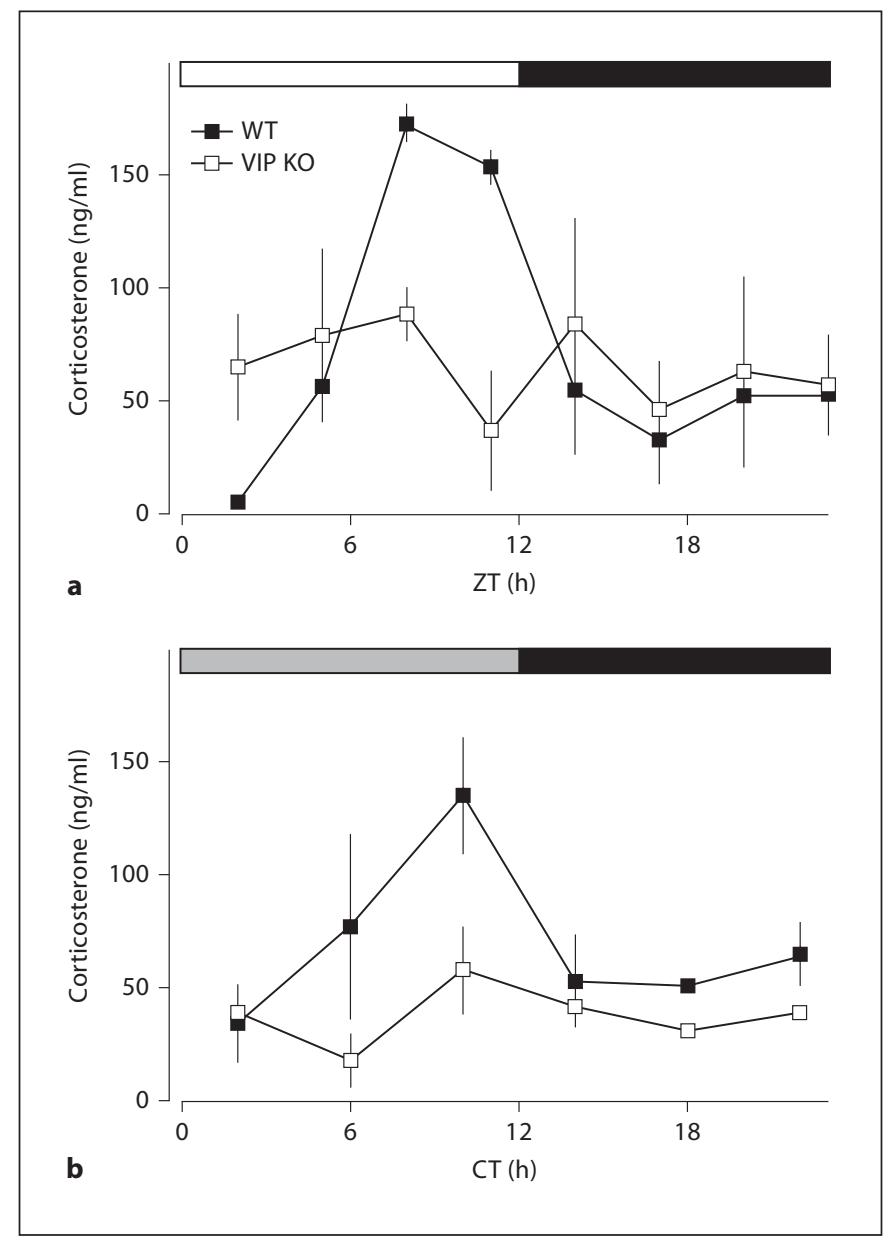

Fig. 1. Concentration of corticosterone in serum over a 24-hour period in wild-type (WT) and Vip $^{-/-}$(VIP KO) mice. Serum was sampled every $3 \mathrm{~h}$ ( $\mathrm{n}=3$ per time point) under light-dark conditions (LD) and every $4 \mathrm{~h}$ under constant darkness (DD). Circulating corticosterone concentration $(\mathrm{ng} / \mathrm{ml})$ was determined by ELISA. a Serum corticosterone concentration under 12:12 LD conditions plotted against zeitgeber time (ZT). The WT peak in corticosterone at ZT8 was 30-fold higher than the trough at ZT2 and cycling conditions for WT concentrations were determined to be significant $(\mathrm{p}<0.001)$ by ANOVA. In contrast, VIP KO mice displayed no such rhythmicity in basal concentration of corticosterone. b Corticosterone measurements plotted against circadian time (CT) in DD. Again, WT concentrations were determined to be significantly different by ANOVA $(p<0.05)$ with a 4 -fold difference between peak and trough values at CT10 and CT2, respectively.

tion of ACTH in VIP KO mice is considerably higher than in WT mice. This observation is consistent with a loss of the negative feedback regulation of ACTH by corticosterone.

VIP Is Critical for Glucocorticoid Rhythms

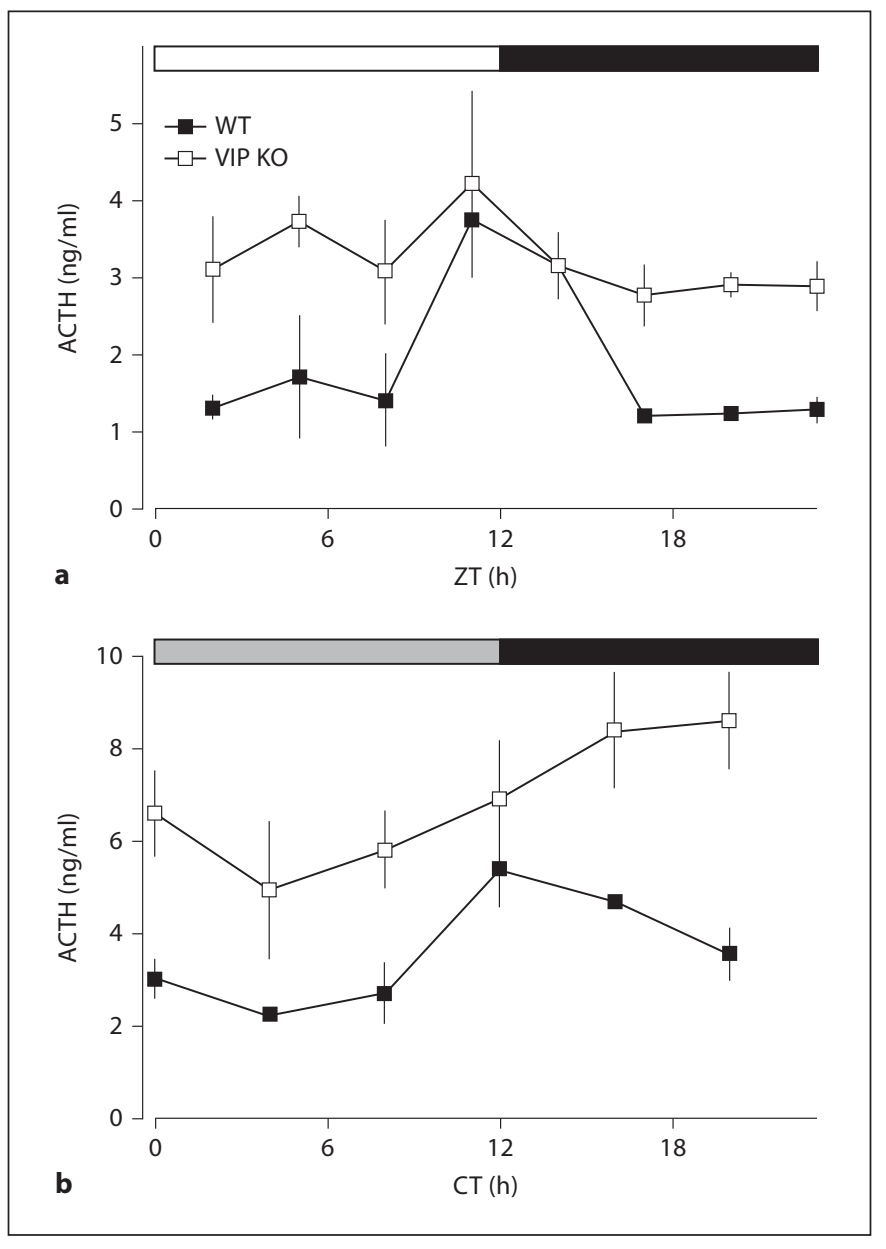

Fig. 2. ACTH measurements from WT and VIP KO mice in LD plotted against ZT (a) and DD plotted against CT (b). Concentration of ACTH in the serum was determined by ELISA in 3-hour intervals in LD and 4-hour intervals in DD ( $\mathrm{n}=2$ or 3 for every time point). Circulating ACTH concentrations were found to be significantly rhythmic by ANOVA $(p<0.01)$ for WT mice in LD and DD. The peak concentration of diurnal (LD) ACTH was determined to be at ZT11, and was 3-fold higher than at ZT2. Under $\mathrm{DD}, \mathrm{ACTH}$ concentration peaked at CT12, where it was found to be 2-fold higher than at CT4. In contrast, VIP KO mice did not display rhythmicity under either LD or DD, with circulating corticosterone concentrations remaining high throughout the 24hour period.

Feedback Regulation in the HPA Axis of $\mathrm{Vip}^{-/-}$Mice

One measure of corticosterone feedback in the HPA axis is that ACTH secretion increases in response to the removal of the adrenal glands. In this set of experiments, we sought to determine whether this negative feedback 


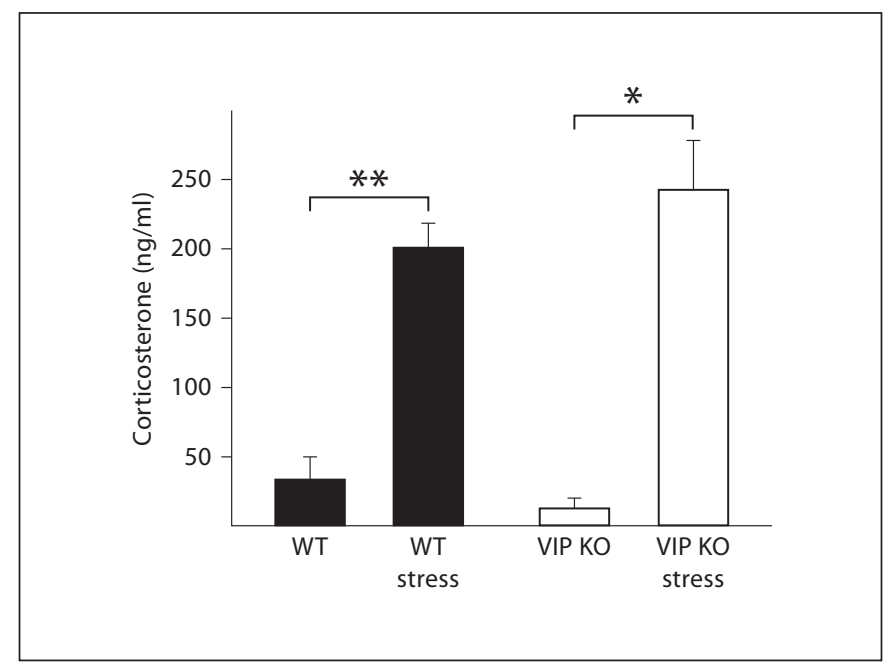

Fig. 3. Corticosterone response to acute stress by footshock in early night (ZT15). WT mice displayed a significant induction of corticosterone in response to acute stress (baseline: $33.63 \pm 16.07$ $\mathrm{ng} / \mathrm{ml}, \mathrm{n}=5$, vs. stress: $201.30 \pm 17.16 \mathrm{ng} / \mathrm{ml}, \mathrm{n}=5$; $^{* *} \mathrm{p}<0.01$ ). A similar corticosterone response to acute stress was also observed in VIP KO mice (baseline: $13.14 \pm 6.49 \mathrm{ng} / \mathrm{ml}, \mathrm{n}=3$, vs. stress $243.00 \pm 35.39 \mathrm{ng} / \mathrm{ml}, \mathrm{n}=6$; $\left.{ }^{*} \mathrm{p}<0.05\right)$. Statistical significances were determined by nonparametric Mann-Whitney $\mathrm{t}$ tests.

response is altered in VIP-deficient mice. As a control, we first confirmed that removing the adrenals (ADX) results in the sharp reduction of serum corticosterone concentration in both WT and VIP-deficient mice (WT sham $167.5 \pm 27.66 \mathrm{ng} / \mathrm{ml}, \mathrm{n}=4$; WT ADX $14.02 \pm 4.58 \mathrm{ng} / \mathrm{ml}$, $\mathrm{n}=8$; VIP KO sham $72.26 \pm 28.12 \mathrm{ng} / \mathrm{ml}, \mathrm{n}=4$; VIP KO ADX $10.28 \pm 2.94 \mathrm{ng} / \mathrm{ml}, \mathrm{n}=7)$. WT mice exhibited a robust increase $(\mathrm{p}<0.01)$ in serum concentration of ACTH in response to the removal of the adrenal glands (WT sham $0.52 \pm 0.11 \mathrm{ng} / \mathrm{ml}, \mathrm{n}=4$; WT ADX $1.68 \pm$ $0.22 \mathrm{ng} / \mathrm{ml}, \mathrm{n}=8)$. VIP-deficient mice started with high concentrations of ACTH (VIP KO sham $1.18 \pm 0.48 \mathrm{ng}$ / $\mathrm{ml}, \mathrm{n}=4$ ), which remained high after adrenalectomy (VIP KO ADX $1.08 \pm 0.21 \mathrm{ng} / \mathrm{ml}, \mathrm{n}=7$ ). The similar serum concentration of ACTH before and after adrenalectomy in the VIP KO mice suggests aberrations in the negative feedback of corticosterone on CRF or ACTH directly.

\section{Acute Stress Corticosterone Response}

While the concentration of circulating corticosterone fluctuates with the 24-hour cycle, in a shorter time scale, the concentration of this hormone is actively regulated as part of the stress response exhibited by mice. We sought

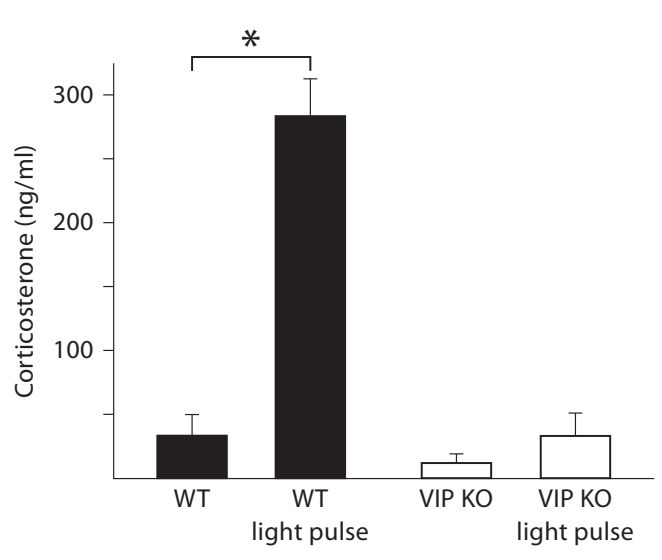

Fig. 4. Corticosterone induction by exposure to light in early night (ZT16). Serum corticosterone from untreated mice $(\mathrm{n}=4)$ and mice subjected to a light treatment $\left(15 \mu \mathrm{W} / \mathrm{cm}^{2}, 30 \mathrm{~min}\right.$ duration, $\mathrm{n}=4$ ) were determined by ELISA. WT mice respond to the light with a significance increase in circulating corticosterone concentration $\left(283.60 \pm 28.84 \mathrm{ng} / \mathrm{ml} ;{ }^{*} \mathrm{p}<0.05\right)$, but VIP KO mice failed to show a significant corticosterone response (33.42 $\pm 17.79 \mathrm{ng} / \mathrm{ml})$.

to determine whether the endocrine response to an acute stressor is altered in VIP-deficient mice. For these experiments, we examined corticosterone response to a mild footshock in WT and VIP KO mice in early night (ZT15). WT mice subjected to footshock exhibited significantly higher concentrations $(\mathrm{p}<0.01)$ of serum corticosterone than unstressed mice (fig. 3), and VIP KO mice showed a similar increase in corticosterone concentration upon exposure to acute stress $(\mathrm{p}<0.05)$. Serum corticosterone concentration upon acute stress was not significantly different between WT and VIP KO mice, suggesting the induction of corticosterone in response to stress is intact in VIP-deficient mice.

\section{Light-Induced Corticosterone Production}

Light treatment during early night has been shown to increase circulating corticosterone concentration in an ACTH-independent manner [19]. To test the role of VIP in the photic induction of corticosterone, we exposed WT and VIP KO mice to light (30 min duration) in early night (ZT16) and sampled serum $60 \mathrm{~min}$ after initial exposure to light. We observed a significant increase in corticosterone concentration in WT mice following the light pulse ( $p<0.05$; fig. 4 ), confirming the previous study. In con- 


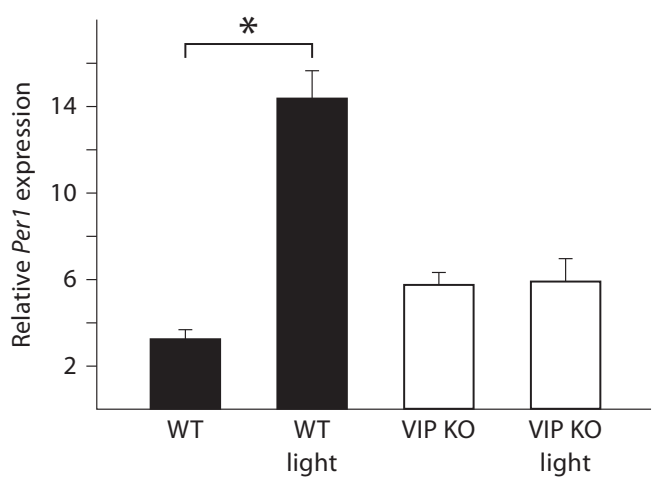

Fig. 5. Photic induction of Perl in the adrenal glands. $60 \mathrm{~min}$ after the start of the light treatment in early night (CT16;15 $\mu \mathrm{W} / \mathrm{cm}^{2}$, 30 min duration), adrenal glands were removed for RNA analysis by quantitative RT-PCR. Expression levels of Per1 were normalized to Hprt using the $2^{-\Delta \Delta \mathrm{Ct}}$ method. WT mice showed a significant increase in relative Perl expression (baseline: $3.29 \pm 0.43$, $\mathrm{n}=4$; vs. light pulse $\left.14.37 \pm 1.27, \mathrm{n}=4 ;{ }^{*} \mathrm{p}<0.001\right)$. VIP KO mice did not show a significant increase in Perl expression (baseline: $5.76 \pm 0.59, \mathrm{n}=4$; vs. light pulse $5.93 \pm 1.01, \mathrm{n}=4$ ).

trast, VIP KO mice failed to exhibit a significant induction of corticosterone in response to light, thus demonstrating a deficit in the light-responsive aspect of the HPA axis in VIP-deficient mice.

\section{Measurement of Per1 Expression in the Adrenal}

Glands following Light Treatment and Acute Stress

To further study the effect of the loss of VIP on photic induction in the periphery, we exposed WT and VIP KO mice to a 30-min light treatment in early night (CT16) and determined Perl expression in the adrenal glands 60 min after initiation of the light treatment. A significant increase in Perl expression levels was observed in the adrenal glands of WT mice 60 min after the initiation of the light pulse ( $\mathrm{p}<0.001$; fig. 5). In contrast, measurement of Perl expression following light treatment was not significantly higher in VIP KO mice. Acute stress evoked by mild footshock in early night (ZT15) also increased Per1 expression in adrenal glands. Perl expression was increased 2.7-fold in WT mice (baseline: $6.16 \pm 0.44, \mathrm{n}=$ 3 ; vs. stress $16.65 \pm 1.23, \mathrm{n}=3$; $\mathrm{p}<0.005)$. VIP KO mice also displayed a significant, albeit blunted, 1.7-fold increase (baseline: $4.67 \pm 0.60, \mathrm{n}=3$; vs. stress $7.94 \pm 0.96$, $\mathrm{n}=3 ; \mathrm{p}<0.05)$ in Per1 expression. These gene expression results corroborate our finding that the loss of VIP does not affect some aspects of the HPA axis, but is critical for response to light.

\section{Discussion}

The secretion of glucocorticoid hormones is a highly regulated process. One of the important regulators of the HPA axis is circadian information originating in the SCN. This temporal information is critical for coordination of whole body physiology, preparing the body for daily changes between activity and rest. The SCN can be divided into two anatomically distinct portions based on the expression patterns of two neuropeptides: VIP and vasopressin (AVP). VIP-ir fibers make up the 'core', which receives input from the retinohypothalamic tract (RHT) and in all likelihood signals to the 'shell', made up of AVP-ir neurons. It is postulated that the AVP neurons, situated next to the third ventricle, play a neurosecretory role. Both VIP-ir and AVP-ir fibers have been found to innervate various hypothalamic nuclei [20-23]. In particular, VIP-ir fibers in the PVN show a similar distribution to transcripts of the $\mathrm{VPAC}_{2}$ receptor [24]. This anatomical distribution of VIP and $\mathrm{VPAC}_{2} \mathrm{R}$ strongly suggests the importance of VIP in SCN to PVN communication, and may be critical for transmission of circadian signals to the HPA axis.

The necessity of VIP and its receptor in the SCN, $\mathrm{VPAC}_{2} \mathrm{R}$, for rhythms in electrical activity in SCN neurons and behavioral rhythms has been previously demonstrated $[12,14-16,25]$. We now demonstrate that diurnal and circadian rhythms of serum concentration of ACTH and corticosterone are lost in VIP-deficient mice. As such, we propose that VIP, and likely its receptor $\mathrm{VPAC}_{2} \mathrm{R}$, are critical for the daily rhythms of glucocorticoids by their action to maintain rhythmicity and synchrony within the SCN.

The $\mathrm{VPAC}_{2} \mathrm{R}$ knockout mice show a lack of rhythms in expression levels of clock genes [14] and glucocorticoid rhythmicity [26]. We would predict a similar loss in clock gene rhythmicity in VIP-deficient mice. Mutants in clock genes, e.g. the Period and Cryptochrome genes, show a variety of circadian defects. In particular, the Per $2 / C r y 1$ double knockout model shows a lack of glucocorticoid rhythms [27]. In this instance, the authors determined that a functional oscillator in the SCN is necessary for the rhythms in ACTH and that a circadian rhythm in corticosterone is dependent on the oscillator in adrenals. They 
suggest the adrenals can modulate production of corticosterone in a manner dependent on time of day. Their data and ours highlight the importance of a function$\mathrm{al} / \mathrm{rhythmic}$ SCN in determining rhythmicity in the periphery. It remains to be seen if the VIP-deficient mice have functional peripheral oscillators and if such oscillators require a daily rhythm in glucocorticoids for synchrony with the SCN.

Other dimensions of VIP action in the HPA axis could be within the adrenals, where VIP has been shown to be synthesized in adrenal glands [28, 29]. VIP-ir fibers innervate both the cortex and medulla of adrenal glands and originate from the splanchnic nerve or from ganglion cells in the medulla [30,31]. Both receptors for VIP, $\mathrm{VPAC}_{1} \mathrm{R}$ and $\mathrm{VPAC}_{2} \mathrm{R}$, are also found in the adrenal medulla and capsule $[32,33]$. The role of VIP in the adrenal glands is not entirely clear; functional studies have demonstrated a response by VIP to ACTH administration and splanchnic nerve stimulation as well as effects of VIP on glucocorticoid secretion by the adrenal glands $[28,34$, 35]. Splanchnic denervation in rats has been shown to influence the diurnal rhythm of corticosterone production, either by sympathetic signals to directly induce corticosterone production or in adapting the adrenal responsiveness to ACTH [36]. This suggests that some form of interaction between the HPA axis and the autonomic nervous system controls corticosterone rhythmicity.

In our study, VIP-deficient mice maintain their capacity to produce corticosterone; basal concentrations, while not rhythmic, are similar to non-peak concentrations in WT mice, suggesting that VIP signaling is not critical for normal adrenal production of corticosterone. Alternatively, if VIP does play a role within the adrenals in interpretation of the ACTH or splanchnic nerve signal, other neuropeptides, like PACAP or AVP, may play a compensatory role in the mutant mice. While PACAP has been implicated in a number of stress responses [e.g. 37, 38], recent data makes it less likely that an up-regulation of PACAP may compensate for the loss of VIP [39]. The basal concentration of ACTH is significantly higher in the VIP-deficient mice at all time points tested. This raises the question of whether the loss of the ACTH rhythm is due to a breakdown in its circadian control or if VIP is necessary for the repression of ACTH from the pituitary. Adrenalectomy normally results in the loss of the major source of circulating corticosterone and a corresponding increase in ACTH. Prior to adrenalectomy, ACTH concentration in VIP mutants is already significantly higher than in WT mice, and remains high following adrenalectomy. The high basal concentration of ACTH may indi- cate defects in the ability of corticosterone to feedback on CRF-releasing neurons in the PVN.

One of the key components driven by the HPA axis is the rapid release of ACTH and adrenal corticosterone into the circulation in response to a variety of stressors (like noise, restraint, footshock, immune challenge, hypoglycemia, hemorrhage, novel environment, predator exposure). This responsiveness of the HPA axis has a diurnal rhythm, and the magnitude of the corticosteroid response to stress is stressor specific. Stress by ether and novel environment has been reported to produce a greater corticosterone response at the start of the active phase [40], with restraint stress inducing a larger response in the early day $[6,41]$. Lesioning the SCN causes a loss in the diurnal difference in response, but not the ability to respond [6]. Furthermore, application of anti-sense VIP transcripts by intracranial infusion into the hypothalamic region transiently blunts the corticosterone rhythm without affecting corticosterone production in response to acute stress [42]. In support of this, our study shows that mice lacking VIP not only in the hypothalamus but also in the adrenals are capable of mounting a normal corticosterone response to acute stress. Taken together with the ability of VIP-deficient mice to maintain normal basal concentration of corticosterone, we can conclude that VIP is not essential for non-circadian functioning of the HPA axis.

Light acts to entrain the circadian clock and synchronizes it to the environment. The term circadian is literally translated to 'about a day', and the free-running period of nocturnal animals tends to be just under $24 \mathrm{~h}$. As such, under conditions of LD of 12:12 or normal changing LD patterns in the wild, light synchronizes the circadian clock daily by shifting the phase of the oscillator [43]. The ability of light to shift the endogenous clock is well documented, and even brief pulses of light (from seconds to minutes) can effect a change in the rhythm of locomotor behavior and shift peripheral molecular oscillators [e.g. 44]. The phase shifting effect of light has been shown to pass through the RHT to VIP neurons in the SCN [45], modifying the concentration of one of the clock genes, Per1 [46], and changing the phase of the molecular oscillator. The SCN is necessary for light-induced changes in the adrenals: in SCN-lesioned rodents, there was no corticosterone induction nor Perl up-regulation [19]. This adrenal response is also dependent on the integrity of the splanchnic nerve $[19,47,48]$. In response to exposure to light in the early night, we observed an increase in corticosterone concentration in WT mice, in agreement with evidence from Ishida and colleagues [19]. In 
contrast, VIP mutant mice are deficient in this light-induced response, suggesting that VIP is critical for interpretation of light input.

We also showed that we can measure a significant upregulation of Perl expression following light treatment in WT mice. This response is lost in VIP KO mice, providing further evidence of a defect in response to light. The Perl response to a different acute stressor, footshock, remains present, if blunted, in VIP KO mice, again confirming that some aspects of the HPA axis are unaffected by the loss of VIP. The selective deficits in behavioral, hormonal and gene expression response to light continue to be the most intriguing aspects of VIP loss. It remains to be determined if this deficiency is due to loss of VIP in the SCN or a breakdown of signaling in the rest of the HPA axis that may be dependent on VIP.

There are many peripheral organs in which rhythms in gene expression have been demonstrated, including the liver and adrenal glands [49-51]. For the SCN to synchronize the molecular oscillators in the periphery, there must be an entraining or resetting signal originating from the SCN. This could take a number of forms, including direct secretion from secretory AVP-ir neurons next to the third ventricle, neurotransmitters through the autonomic nervous system, or activation of the HPA axis [52]. There is a growing body of evidence for the HPA axis as an output of the SCN. A glucocorticoid receptor agonist, dexamethasone, can induce Perl expression in the liver with subsequent phase shifting of the liver oscillator [3]. Further evidence comes from food-restriction studies, where loss of endogenous corticosterone by adrenalectomy has been found to speed up synchronization of the liver oscillator to food-restriction regimes [53]. Indications of the possible roles corticosterone could play as an output signal were teased out in a study where the rhythmicity of genes involved in glycogenesis, gluconeogenesis and cholesterol synthesis, amongst other pathways, in the liver were affected by adrenalectomy [54]. Another striking effect of adrenalectomy on circadian rhythms in non-SCN tissues is the loss of PER2 rhythms in the oval nucleus of stria terminalis and the central nucleus of the amygdala in rats, which can be rescued by rhythmic application of corticosterone [55].

The VIP knockout mouse provides a unique model in which the circadian information from the SCN is lost or not transmitted. So far, we have determined that rhythms in glucocorticoids are lost even though the ability of the HPA axis to respond to acute stress is intact. It is reasonable to assume that other endocrine rhythms are lost as well. This unique dissociation of circadian and responsive aspects of the HPA axis thus makes VIP-deficient mice a good model for dissecting out downstream physiological processes that require signals from the SCN. Conversely, it may also prove a useful model in which to study the HPA axis without the confounding effect of circadian regulation. Furthermore, the deficient corticosterone response to light provides an interesting avenue to explore the mechanisms by which light signals from the environment change physiological state.

\section{Acknowledgements}

This research was supported by NIH grants NS-043169 to C.S.C. and MH-65497 to J.A.W.

\section{References}

$>1$ Hastings MH, Reddy AB, Maywood ES: A clockwork web: circadian timing in brain and periphery, in health and disease. Nat Rev Neurosci 2003;4:649-661.

$\checkmark 2$ Schibler U, Ripperger J, Brown SA: Peripheral circadian oscillators in mammals: time and food. J Biol Rhythms 2003;18:250-260.

$>3$ Balsalobre A, Brown SA, Marcacci L, Tronche F, Kellendonk C, Reichardt HM, Schutz G, Schibler U: Resetting of circadian time peripheral tissues by glucocorticoid signaling. Science 2000;289:2344-2347.

4 Swanson LW, Sawchenko PE, Rivier J, Vale WW: Organization of ovine corticotropinreleasing factor immunoreactive cells and fibers in the rat brain: an immunohistochemical study. Neuroendocrinology 1983;36: 165-186.
75 Moore RY, Eichler VB: Loss of a circadian adrenal corticosterone rhythm following suprachiasmatic lesions in the rat. Brain Res 1972;42:201-206.

-6 Sage D, Maurel D, Bosler O: Involvement of the suprachiasmatic nucleus in diurnal $\mathrm{ACTH}$ and corticosterone responsiveness to stress. Am J Physiol Endocrinol Metab 2001; 280:E260-E269.

$\checkmark 7$ Buijs RM, Kalsbeek A, van der Woude TP, van Heerikhuize JJ, Shinn S: Suprachiasmatic nucleus lesion increases corticosterone secretion. Am J Physiol 1993;264:R1186R1192.
8 Meyer-Bernstein EL, Jetton AE, Matsumoto SI, Markuns JF, Lehman MN, Bittman EL: Effects of suprachiasmatic transplants on circadian rhythms of neuroendocrine function in golden hamsters. Endocrinology 1999;140:207-218.

$\checkmark 9$ Teclemariam-Mesbah R, Kalsbeek A, Pevet P, Buijs RM: Direct vasoactive intestinal polypeptide-containing projection from the suprachiasmatic nucleus to spinal projecting hypothalamic paraventricular neurons. Brain Res 1997;748:71-76.

10 Buijs RM, Wortel J, van Heerikhuize JJ, Feenstra MGP, Ter Horst GJ, Romijn HJ, Kalsbeek A: Anatomical and functional demonstration of a multisynaptic suprachiasmatic nucleus adrenal (cortex) pathway. Eur J Neurosci 1999;11:1535-1544. 
11 Alexander LD, Sander LD: Vasoactive intestinal peptide stimulates ACTH and corticosterone release after injection into the PVN. Regul Peptides 1994;51:221-227.

$\checkmark 12$ Colwell CS, Michel S, Itri J, Rodriguez W, Tam J, Lelievre V, Hu Z, Liu X, Waschek JA: Disrupted circadian rhythms in VIP- and PHI-deficient mice. Am J Physiol Regul Integr Comp Physiol 2003;285:R939-R949.

$\checkmark 13$ Reed HE, Meyer-Spasche A, Cutler DJ, Coen CW, Piggins HD: Vasoactive intestinal polypeptide (VIP) phase-shifts the rat suprachiasmatic nucleus clock in vitro. Eur J Neurosci 2001;13:839-843.

14 Harmar AJ, Marston HM, Shen S, Spratt C, West KM, Sheward WJ, Morrison CF, Dorin JR, Piggins HD, Reubi JC, Kelly JS, Maywood ES, Hastings MH: The VPAC(2) receptor is essential for circadian function in the mouse suprachiasmatic nuclei. Cell 2002;109:497508.

-15 Aton SJ, Colwell CS, Harmar AJ, Waschek J, Herzog ED: Vasoactive intestinal polypeptide mediates circadian rhythmicity and synchrony in mammalian clock neurons. Nat Neurosci 2005;8:476-483.

- 16 Brown TM, Colwell CS, Waschek JA, Piggins HD: Disrupted neuronal activity rhythms in the suprachiasmatic nuclei of vasoactive intestinal polypeptide-deficient mice. J Neurophysiol 2007;97:2553-2558.

17 Chaudhury D, Colwell CS: Circadian modulation of learning and memory in fear-conditioned mice. Behav Brain Res 2002;133: 95-108.

18 Zuker M: Mfold web server for nucleic acid folding and hybridization prediction. Nucleic Acids Res 2003;31:3406-3415.

-19 Ishida A, Mutoh T, Ueyama T, Bando H, Masubuchi S, Nakahara D, Tsujimoto G, Okamura H: Light activates the adrenal gland: timing of gene expression and glucocorticoid release. Cell Metab 2005;2:297-307.

-20 Besson J, Rotsztejn W, Laburthe M, Epelbaum J, Beaudet A, Kordon C, Rosselin G: Vasoactive intestinal peptide (VIP): brain distribution, subcellular localization and effect of deafferentation of the hypothalamus in male rats. Brain Res 1979;165:79-85.

21 Hoorneman EM, Buijs RM: Vasopressin fiber pathways in the rat brain following suprachiasmatic nucleus lesioning. Brain Res 1982;243:235-241.

22 Mezey E, Kiss JZ: Vasoactive intestinal peptide-containing neurons in the paraventricular nucleus may participate in regulating prolactin secretion. Proc Natl Acad Sci USA 1985;82:245-247.

23 Watts AG, Swanson LW, Sanchez-Watts G: Efferent projections of the suprachiasmatic nucleus. I. Studies using anterograde transport of Phaseolus vulgaris leucoagglutinin in the rat. J Comp Neurol 1987;258:204-229.
24 Kallo I, Kalamatianos T, Wiltshire N, Shen S, Sheward WJ, Harmar AJ, Coen CW: Transgenic approach reveals expression of the VPAC2 receptor in phenotypically defined neurons in the mouse suprachiasmatic nucleus and in its efferent target sites. Eur J Neurosci 2004;19:2201-2211.

25 Maywood ES, Reddy AB, Wong GK, O’Neill JS, O’Brien JA, McMahon DG, Harmar AJ, Okamura H, Hastings MH: Synchronization and maintenance of timekeeping in suprachiasmatic circadian clock cells by neuropeptidergic signaling. Curr Biol 2006;16: 599-605.

26 Sheward WJ, Maywood ES, French KL, Horn JM, Hastings MH, Seckl JR, Holmes MC, Harmar AJ: Entrainment to feeding but not to light: circadian phenotype of VPAC2 receptor-null mice. J Neurosci 2007;27:43514358.

27 Oster H, Damerow S, Kiessling S, Jakubcakova V, Abraham D, Tian J, Hoffmann MW, Eichele G: The circadian rhythm of glucocorticoids is regulated by a gating mechanism residing in the adrenal cortical clock. Cell Metab 2006;4:163-173.

28 Bodnar M, Sarrieau A, Deschepper CF, Walker CD: Adrenal vasoactive intestinal peptide participates in neonatal corticosteroid production in the rat. Am J Physiol Regul Integr Comp Physiol 1997;42:R1163R1172.

29 Hinson JP, Renshaw D, Carroll M, Kapas S: Regulation of rat adrenal vasoactive intestinal peptide content: effects of adrenocorticotropic hormone treatment and changes in dietary sodium intake. J Neuroendocrinol 2001;13:769-773.

30 Cunningham LA, Holzwarth MA: Autoradiographic distribution of 125I-VIP binding in the rat adrenal cortex. Peptides 1989;10: 1105-1108.

31 Holzwarth MA: The distribution of vasoactive intestinal peptide in the rat adrenal cortex and medulla. J Auton Nerv Syst 1984;11: 269-283.

32 Karacay B, O’Dorisio MS, Summers M, Robinson M, Bonthius DJ: VIP receptor 1 (VPAC1) promoter targets the expression of a reporter gene to cerebellum and adrenal medulla in transgenic mice. Regul Pept 2003; 116:1-12.

33 Harmar AJ, Sheward WJ, Morrison CF, Waser B, Gugger M, Reubi JC: Distribution of the VPAC2 receptor in peripheral tissues of the mouse. Endocrinology 2004;145:1203-1210.

34 Ehrhart-Bornstein M, Bornstein SR, Scherbaum WA, Pfeiffer EF, Holst JJ: Role of the vasoactive intestinal peptide in a neuroendocrine regulation of the adrenal cortex. Neuroendocrinology 1991;54:623-628.

35 Cunningham LA, Holzwarth MA: Vasoactive intestinal peptide stimulates adrenal aldosterone and corticosterone secretion. Endocrinology 1988;122:2090-2097.
36 Dijkstra I, Binnekade R, Tilders FJ: Diurnal variation in resting levels of corticosterone is not mediated by variation in adrenal responsiveness to adrenocorticotropin but involves splanchnic nerve integrity. Endocrinology 1996;137:540-547.

37 Morita Y, Yanagida D, Shintani N, Ogita K, Nishiyama N, Tsuchida R, Hashimoto $\mathrm{H}$, Baba A: Lack of trimethyltin (TMT)-induced elevation of plasma corticosterone in PACAP-deficient mice. Ann NY Acad Sci 2006; 1070:450-456

38 Agarwal A, Halvorson LM, Legradi G: Pituitary adenylate cyclase-activating polypeptide (PACAP) mimics neuroendocrine and behavioral manifestations of stress: Evidence for PKA-mediated expression of the corticotropin-releasing hormone $(\mathrm{CRH})$ gene. Brain Res Mol Brain Res 2005;138:45-57.

-39 Girard BA, Lelievre V, Braas KM, Razinia T, Vizzard MA, Ioffe Y, El Meskini R, Ronnett GV, Waschek JA, May V: Noncompensation in peptide/receptor gene expression and distinct behavioral phenotypes in VIP- and PACAP-deficient mice. J Neurochem 2006;99: 499-513.

40 Dunn J, Scheving L, Millet P: Circadian variation in stress-evoked increases in plasma corticosterone. Am J Physiol 1972;223:402406.

41 Kant GJ, Mougey EH, Meyerhoff JL: Diurnal variation in neuroendocrine response to stress in rats: plasma ACTH, beta-endorphin, beta-LPH, corticosterone, prolactin and pituitary cyclic AMP responses. Neuroendocrinology 1986;43:383-390.

42 Scarbrough K, Harney JP, Rosewell KL, Wise PM: Acute effects of antisense antagonism of a single peptide neurotransmitter in the circadian clock. Am J Physiol 1996;270:R283$\mathrm{R} 288$.

43 Roenneberg T, Daan S, Merrow M: The art of entrainment. J Biol Rhythms 2003;18:183194.

44 Sakamoto K, Ishida N: Light-induced phaseshifts in the circadian expression rhythm of mammalian period genes in the mouse heart. Eur J Neurosci 2000;12:4003-4006.

45 Kawamoto K, Nagano M, Kanda F, Chihara $\mathrm{K}$, Shigeyoshi Y, Okamura H: Two types of VIP neuronal components in rat suprachiasmatic nucleus. J Neurosci Res 2003;74:852857.

46 Shigeyoshi Y, Taguchi K, Yamamoto S, Takekida S, Yan L, Tei H, Moriya T, Shibata S, Loros JJ, Dunlap JC, Okamura H: Lightinduced resetting of a mammalian circadian clock is associated with rapid induction of the mPerl transcript. Cell 1997;91:10431053.

47 Jasper MS, Engeland WC: Splanchnic neural activity modulates ultradian and circadian rhythms in adrenocortical secretion in awake rats. Neuroendocrinology 1994;59: 97-109. 
48 Jasper MS, Engeland WC: Splanchnicotomy increases adrenal sensitivity to ACTH in nonstressed rats. Am J Physiol 1997;273: E363-E368.

49 Bittman EL, Doherty L, Huang L, Paroskie A: Period gene expression in mouse endocrine tissues. Am J Physiol Regul Integr Comp Physiol 2003;285:R561-R569.

50 Oster H, Damerow S, Hut RA, Eichele G: Transcriptional profiling in the adrenal gland reveals circadian regulation of hormone biosynthesis genes and nucleosome assembly genes. J Biol Rhythms 2006;21:350361.
51 Yoo SH, Yamazaki S, Lowrey PL, Shimomura K, Ko CH, Buhr ED, Siepka SM, Hong HK, Oh WJ, Yoo OJ, Menaker M, Takahashi JS: PERIOD2::LUCIFERASE real-time reporting of circadian dynamics reveals persistent circadian oscillations in mouse peripheral tissues. Proc Natl Acad Sci USA 2004;101: 5339-5346.

52 Kalsbeek A, Palm IF, La Fleur SE, Scheer FAJL, Perreau-Lenz S, Ruiter M, Kreier F, Cailotto C, Buijs RM: SCN outputs and the hypothalamic balance of life. J Biol Rhythms 2006;21:458-469.

53 Le Minh N, Damiola F, Tronche F, Schutz G, Schibler U: Glucocorticoid hormones inhibit food-induced phase-shifting of peripheral circadian oscillators. EMBO J 2001;20:71287136.
54 Oishi K, Amagai N, Shirai H, Kadota K, Ohkura N, Ishida N: Genome-wide expression analysis reveals 100 adrenal gland-dependent circadian genes in the mouse liver. DNA Res 2005;12:191-202.

55 Segall LA, Perrin JS, Walker CD, Stewart J, Amir S: Glucocorticoid rhythms control the rhythm of expression of the clock protein, Period2, in oval nucleus of the bed nucleus of the stria terminalis and central nucleus of the amygdala in rats. Neuroscience 2006; 140:753-757. 